\title{
Constructing Modern Indonesia Based on Pancasila in Dialogue with the Political Concepts Underlying the Idea of Human Rights
}

Otto Gusti Madung

Lecturer at the Ledalero Catholic School of Philosophy, Indonesia

Email: ottomadung@gmail.com

Winibaldus Stefanus Mere

Associate Professor Faculty of Law and Senior Research Fellow at Institute for Social Ethics, Nanzan University, Nagoya, Japan

Email: merestef@nanzan-u.ac.jp

\begin{abstract}
This article examines the role of 'Pancasila' as an ideological basis and collective identity for Indonesia's multicultural society. Indonesian history demonstrates the power of Pancasila in uniting the nation's diverse peoples and cultures. Pancasila relates to five principles that construct the ethical basis for one common home, i.e. Indonesia. The five principles are as follows: belief in one God; humanity; Indonesia's national unity; representative democracy; and social justice for all Indonesian citizens. This article argues that, in the midst of democratisation and the openness to globalisation, Pancasila needs to be re-interpreted to secure a place and remain relevant in contemporary political discourse. It proposes that Pancasila should be read in light of dialogue between communitarian and liberal discourses. Such a dialogue is necessary to cope with the dogmatisation of Pancasila and conflicting values which can result in the loss of its political relevance as a collective identity. Furthermore, liberalism and communitarianism are the two fundamental philosophical pillars, beside socialism, upon which the concept of human rights has been developed. Therefore, combining Pancasila with these two philosophical concepts is very important to strengthen the role of Pancasila in promoting the idea and practice of human rights in Indonesia.
\end{abstract}

Keywords: Pancasila, Indonesia, Communitarianism, Liberalism, Human Rights 


\section{INTRODUCTION}

Indonesia's first steps toward independence were augmented by the emergence of two interest groups - the Religiously Neutral Nationalists and the Muslim Nationalists who sought to establish the ideological foundation of the newly independent nation.' The Religously Neutral Nationalist, represented by Mohammad Hatta, proposed a national unitary State based on liberalism that would Seprate State and religion. This idea then successfully established the concept of freedom of organisation and freedom of expression in the Indonesian Constitution. ${ }^{2}$ The Muslim Nationalist, represented by Soepomo, proposed an integrated State based in Islam. Integralism was considered compatible with traditional Indonesian values including the principle of cooperation (gotong royong) and the importance of family as a basic unit of society (communalism).

Both Hatta and Soepomo had a very broad understanding of politics, influenced by western political thought. Hatta's liberalism was influenced by Adam Smith, John Locke and J.J. Rousseau. Hatta perceived the political values of the French Revolution - liberty, equality and fraternity - as the basic ideals for an independent Indonesia. ${ }^{3}$ On the other hand, Soepomo's conceptualisation of an integrated State cannot be imagined without a deep intellectual inquiry into Adam Mueller's theory of integralism. Muller's political thought largely followed the intellectual footsteps of Hegel. ${ }^{4}$

Such an intelectual discourse of political thought concerning ideology may seem irrelevant in the midst of today's political pragmatism. Politics that represent certain values are built upon a clear ideology or collective identity. ${ }^{5}$ Historically, Pancasila is an ideology representing collective identity in Indonesia, helping unite the diverse people of Indonesia. Despite the existence various religous, racial and ethnic tensions and conflicts, including radicalism and terrorism, thoughout its history, Indonesia remains firm as a nation. Timor-Leste can be considered an exception because of its separation from Indonesia, partly due to power and political stuggles. In this regard, Pancasila can be seen as an ideological foundation that forms a collective identity for a pluralistic Indonesia.

Crucially, 'collective identity' does not refer to a final and untouchable product. As Chantal Mouffe correctly pointed out, an identity has neven been a finished product, for what is presented as an identiy in a society is a process of constructing the collective

1 Muhammad Yamin, Naskah-persiapan Undang-undang Dasar 1945: disiarkan dengan dububuhi tjatatan (Jakarta: Jajasan Prapantja, 1959).

2 The Consitution of the Republic of Indonesia, 1945 at Art.28.

3 Mohammad Hatta, Kumpulan karangan (Jakarta: Penerbit Bulan Bintang, 1976) at 11.

4 Franz Magnis-Suseno, Pijar-pijar Filsafat: Dari Gatholoco ke Filsafat Perempuan, dari Adam Muller ke Postmodernisme (Yogyakarta: Kanisius, 2005) at 58.

5 Leonie Huddy, David O Sears \& Jack S Levy, Eds, "Values, Ideology, and the Structure of Political Attitudes" in the Oxford Handbook of Political Psychology: Second Edition (Oxford: Oxford University Press, 2003) at 477-508. 
identity which never ends, "Niemals Identität, immer Identifizierungen" (Identity never exists, but rather the process of identification goes on"). ${ }^{6}$

The relevance of reflecting Pancasila as an ideological basis and collective identity of Indonesia arises from the fact that a nation can only survive through its spirit (Geist) which unites all entities within it. Pancasila needs to be reinterpreted in order to establish its relevance in the complex and dynamic context of globalization, and the various social tensions and conflicts that follow. Indonesia must adapt to these changes in order to maintain and stregthen the unity of its pluralistic society. Pancasila provides a philosopical basis with the power to facilitate this process of adaptation.

While there are multiple interpretations of Pancasila, this article adopts an understanding of the term in light of two theories in contemporary political philosophy: liberalism and communitarianism. The debate between liberalism and communitarianism has been a hot issue since the founding of the Republic of Indonesia and remains relevant today. The conversation between these theories during the early period of the Republic is demonstrated in the debate between Soepomo, and his concept of an integral state, and Mohamad Hatta, who contributed to the enshrinement of individual rights in the 1945 Constitution. Liberalism, on Hatta's account, serves as the philosophical foundation of the very idea of human rights, in particular, the first generation of human rights. Hatta had long been aware of the importance of human rights, especially the right to liberty for Indonesia in the future. This raises the question: to what extent can such an opptimistic view hold true in relation to, the state-sponsored terror during the New Order regime and transition period that violated most first generation human rights, and whose truth and justice remains unaddressed by the State?

In contrast to the individualistic sentiment of liberalism, integralism, as proposed by Soepomo, emphasizes the fundamental role of community, collective consciousness, and solidarity in building a nation. Integralism is closely related to second and third generation human rights, in particular social and collective rights. Communitariansm is regarded as a philosophical foundation for social and collective rights. Reading Pancasila through a communitarian lense can strengthen its role in Indonesia by promoting social and collective rights.

How shall Pancasila be read in the lights of this political ideas of liberalism and communitarianism? To what extent can they help to strenghten the collective identity of a pluralistic society of Indonesia? This article aims to answer these two main questions. In order to read Pancasila in light of these theories, it is important to first clarify the relationship between the notion of liberalism and communitarianism.

6 Chantal Mouffe, Über das Politische: Wider die kosmopolitische Illusion (Frankfurt am Main: Suhrkamp Verlag AG, 2007) at 12. 


\section{COMMUNITARIANISM VERSUS LIBERALISM}

The antagonistic political thought of communitarianism versus liberalism arises from the pluralistic nature of modern society. ${ }^{7}$ Indonesia is a perfect example of this, its society is coloured by all kinds of views, values, ideologies and cultural traditions. This diversity is evident not only in the political sphere, but also in private arena. Without a strong foundational ideal or ideology holding the different communities within society together, clashes between different views, values and cultural traditions can create divisions within society, or even lead to its breakdown. The lived reality of pluralistic society raises a number of basic questions, including: What normative foundational element can unite a pluralistic society? Is there any such normative element? How should the complexity of plurality be approached to ensure that the society remains socially cohesive? These kinds of questions are consinuously relevant in a pluralistic society like Indonesia, prone to various tensions and conflicts.

Within political philosophy the discussion of social cohesiveness in a pluralistic society begins with a debate between liberalism and communitarianism. This debate was first raised in the work of John Rawls, A Theory of Justice, first published in 1970 and revised in 1999, which presents a strong foundation for liberalism. ${ }^{8}$ As the starting point for his argument, Rawls raises this basic question: what are the special features of just social institutions? Rawls does not ask, what makes a particular action just or what makes a person good. Rawls' foundational question implies that the formal object of the concept of justice is the basic structure of society. He writes, "Justice is the first virtue of social institutions, as truth is of systems of thought." Rawls perceives society as an association of persons who recognize certain codes of conduct as 'binding' and act accordingly. ${ }^{10}$ However, regardless of the existence of binding rules, self-interest-based conduct may lead to conflicts of interest within society. In order to overcome this conflict and to choose the ideal social arrangement for the construction of a wellordered and functioning society people need a proper concept and principle of justice.

Rawls belived that in a condition characterised by true freedom, meaning no repressive interference from the State, people will use the best from their ability to structure their life and manage the society. ${ }^{12}$ The process of deciding the basic structure of an ideal society begins from an abstracted situation Rawls refers to as the "original

7 Richard Bellamy, Liberalism and Pluralism: Towards a Politics of Compromise (London: Routledge, 1999).

8 John Rawls, A Theory of Justice Revised Edition, revised edition ed (Massachusetts: Harvard University Press, 1999).

$9 \quad$ Ibid at 3.

10 Ibid at 4 .

11 Ibid.

12 Harry Brighouse, Justice (Cambridge: Polity, 2004). 
position". ${ }^{13}$ This position facilitates operates as a neautral point of view from which a fair fundamental agreement can be made. Justice is a product of fair agreement among people. For Rawls, such an agreement can only be considered 'fair' if it is unaffected by the biases held by people, borne out of their position in society. As such, Rawls proposes the need for a "Veil of Ignorance," which removes any knowledge of the participants' social position, status, fortune, intelligence, strength, and interests in society. ${ }^{14}$ Being in the "original position" will mean standing behind the "veil of ignorance". This is a position removes any sense of impartiality in descision making; there is no sense of personal priviledge or preoccupation with personals views about what is 'good' or not. When standing behind the "veil of ignorance," people do not know who they are or will be. ${ }^{15}$ What they really need is knowledge about science and theories that can support their reasonability and rationality when approaching various social issues, ensuring that the decisions made are fair. ${ }^{16}$

Given that those in the original position will not take personal interest or advantage at the cost of other peoples' interests, they will be equiped with two principles of justice when considering how things in a society work: the principle of liberty and the principle of difference. ${ }^{17}$ Firstly, the principle of liberty undelines the fact that each person has an equal right to basic liberties and freedoms insofar as this is compatible with similar liberties and freedoms for others. ${ }^{18}$ Here, Rawls adheres to egalitarianism. The freedom he means is the freedom to think, to follow one's conscience, to gather, etc, which everyone is entitled to. In pluralistic societies, like Indonesia, society as a whole is not organized justly if only one group can express its views or if every citizen is forced to follow a particular religion. Freedom should be as expansive as possible, but there are limitations to it. An individual's freedom is limited by the freedom of others living within the same society. Therefore, the principle of liberty advocates for a social contract that guarantees everyone the enjoyment of maximum liberty without infiringing on the freedoms of others.

Secondly, the difference principle focuses on the necessity of a social contract to guarantee everyone equal opportunity to achieve a prosperous living. Thus, social and economic matters must be managed in such a way that they are: a) reasonably expected to be to everyone's advantage, and b) distributed fairly to everyone in the society as to benefit the least advantaged as well. ${ }^{19}$ Rejecting radical egalitarianism, Rawls argues that for a society to be managed with 'fairness'. As such, difference can exist in a society.

13 Rawls, supra note 8 at 11.

14 Ibid at 11,118 .

15 Ibid at 118-122.

16 Ibid at 123-140; John Rawls, Political Liberalism (New York: Columbia University Press, 1993) at 48-58.

17 Rawls, supra note 8 at 52-56.

18 Ibid at 53.

19 Ibid. 
However, those differences must benefit those who are most in need. For example, it would be considered 'fair' if a State provided special skills-training for the poor, or gave financial assistance to widows and orphans, while not giving those benefits to the betteroff who do not need such support. This practice is 'just' as long as it provides equal opportunity to all, including the most disadvantaged in society. The same standard of fairness should be applied to all positions in society. Difference in society is thus considered fair as long as it ensures the greatest benefit to the least advantaged and all positions. ${ }^{20}$

In a complex condition of a social contract in the form of a pluralistic society like Indonesia, the application of these two principles of justice can be useful to find fair methods for governing the society. In this regard, as Rawls belives, fairness becomes the center of justice. This notion of justice as fairness has provided an ethical foundation for the modern welfare state. In a pluralistic society, this conception of justice is a product of reasonable and rational consideration and is necessary to create and maintain social cohesion. ${ }^{21}$ As both principles are considered reasonable for all humanity, they both find expression in a just society. Social cohesion is built upon a foundation of these two principles of justice, or more concretely, on the basis of the arrangement of social institutions in a liberal-democratic way.

In response to Rawls' liberal conception of justice, communitarian thinkers, such as philosopher Michael Walzer, ${ }^{22}$ emphasize the fact that norms, including those related to justice, are always anchored in the language and culture of a community. Every community has a common view of morality and how to live it. This collective moral view is the normative basis by which a community judges what is 'good' or 'bad' in that community. The communitarian perspective shows that a person cannot be regarded as an unencumbered self $f^{3}$ - the way we approach what we want or seek - as expounded in liberal anthropology. Humanity is understood by the proponents of liberalism as an isolated individual who is floating in an empty space, free of encumbrances. On the other hand, communitarians view humanity as necessarily linked to community life, marked by traditions and social bonds. A social system which does not pay attention to these social aspects limits itself to an understanding of the human person as a legal entity in a realm of freedom. It destroys the social substance of human life. It tends to frame humanity in individualistic manner overlooking the value

20 Ibid at 56 .

21 Hanna Pfeifer, Mara-Daria Cojocaru \& Michael Reder, "Was hält Gesellschaft zusammen? Eine Einführung” in Was hält Gesellschaften zusammen? Der gefährdete Umgang mit Pluralität (Stuttgart: Kohlhammer, 2013) at 9.

22 Michael Walzer, Sphären der Gerechtigkeit: Ein Plädoyer für Pluralität und Gleichheit (Frankfurt am Main: Campus Verlag GmbH, 1992).

23 Michael J Sandel, Liberalism and the Limits of Justice (Cambridge: Cambridge University Press, 1982). 
of solidarity. ${ }^{24}$ Communitarianism develops social anthropology, reviving the Aristotelian concept of humans as social beings.

Using this basic concept of community, Walzer developed the notion of justice in a political community, formed by collective consciousness based on common language, history, and culture. Justice is a relative concept which is always related to the tradition and culture of a community. Walzer rejects Rawls' approach to the principles of justice, arguing that they can only be constructed the context of cultural experience and a concrete historical condition. ${ }^{25}$ Ignoring the concept of experiencing value, which has come from a cultural context and history, is a form of injustice, in Walzer's view. Each community has its own understanding of justice which must be practised and reflected upon. Justice is not an abstract principle that transcends history, but it always has a concrete form. Following this, Walzer views the social meaning of goods defines their distribution. Distribution can only be considered just in connection with the meaning of those goods in a particular community. Justice is rooted in things which express living in a community. ${ }^{26}$

In opposition to liberalism, communitarianism stresses social differences as evidenced in family ties, a culture, a nation, or a moral community. These models of social unity form the basis of social cohesion. If these social connections are not given sufficient attention or if social cohesion is viewed as an abstract principle, then the danger of destroying social bonds is real. It is in this regard that the discussion about Pancasila that has been seen as the force for social cohession, in its relation to the debate of liberalism versus communitarianism finds its relevance. This is pricesely because Indonesia, as a nation, is not an absract entity, but a concrete, pluralistic society that has its own history, cultures, languages, and norms.

\section{PANCASILA, LIBERALISM, AND COMMUNITARIANISM}

The connection between the State and the community, as developed by communitarians, can become a model for the relationship between politics and religion in Indonesia, which is bound together by its national ideology, Pancasila. Including communitarianism in the discussion of the relationship between politics and religions is significant because the politicisation of religion is one of the main crises of values that poses a risk to Indonesia's unity. In line with the communitarian perspective, Pancasila emphasises the social dimensions of human life. Pancasila as the national ideology expresses the need for a concept of justice in the pursuit of a 'good' and prosperous life as a nation. In the light of its similarities with communitarianism, Pancasila can be seen

24 Kathleen Lynch \& Manolis Kalaitzake, "Affective and calculative solidarity: The impact of individualism and neoliberal capitalism” (2018) 23:2 European Journal of Social Theory 238-257.

25 Michael Walzer, "The Communitarian Critique of Liberalism” (1990) 18:1 Political Theory.

26 Walzer, supra note 22 at 443. 
as a critique of a liberal community pathology that can be learned to strengthen the pluralistic community life as a nation.

\section{Pancasila and State-Community Relationship}

Modern principles such as democracy and basic human rights, have become the guiding values for politics in post-reformation Indonesia. Pancasila is seen as an answer for various questions concerning a 'good' community life. This includes the question of how to understand and interpret the universal concept of human rights in varying community contexts across Indonesia. Pancasila prevents the privatisation of public goods, which often characterises liberal societies. ${ }^{27}$ Having said that, since Pancasila is not a static value, it is open for re-interpretation in light of different values, such as basic human rights, to ensure its continued relevance in the Indonesian society and the world.

The orientation of the meaning and values in a society is very much dependent on the social vitality of tradition, culture, religion, ethics, and social. Pancasila is a model for the preservation and vitalization of this social tradition. For this reason, Pancasila must remain in the public arena to ensure its meaning and values are internalised and form the basis of a collective consciousness for the Indonesian people.

Differentiation between modern systems of life function on a basis of cultural prerequisites. The structure of social and legal order based on the concept of basic human rights is one of its necessary conditions. Having a constitution and rational will does not preclude the existance of egoistic, intolerant, criminal, violent, corrupt, or greedy attitudes which have the capacity to destroy a value system. Allowing such attitudes to exist will only create conflict and divisions. As an ideology and a system of national, ethical values, Pancasila provides a framework to support Indonesian people overcoming crises of values that cause chaos or conflict in society.

As noted earlier, reading Pancasila from a communitarian perspective opens the possibility of strengthening social solidarity by acknowledging social and collective human rights. Ignoring the social and collective aspects of human rights, for example with the right to liberty (freedom) can be manipulated by powerful segments of society to accumulate more power. Such accumulation comes at the cost of the rest of the society, particularly the poor and marginalized who are unable to compete economically and politically without affirmative action from the State. ${ }^{28}$ As a result, this will broaden the gap between the rich and the poor, worsening social injustice. Besides that, recognizing the social and collective aspects of human rights is essential to

27 Seno Wibowo Gumbira \& Jamal Wiwoho, "The Implication of the Globalization on the Pancasila-

Based Principles of Local Democracy in Indonesia" (2019) 6:2 Padjadjaran Journal of Law 361-378.

${ }^{28}$ Miodrag Jovanovic, "Recognizing Minority Identities Through Collective Rights" (2005) 27:2 Human

Rights Quarterly 625-651. 
protecting the basic rights of indigenious people, and cultural and religious minorities, preventing situations of tyranny and domination of the majority. In other words, the social and cultural aspects of human rights encourage human and social solidarity and facilitate social justice.

Reinterpreting Pancasila in light of communitarianism can help reinforce social solidarity. Pancasila emphasizes the importance of solidarity in "the unity of Indonesia" (Pilar 3); the principle of "just and civilized humanity" (Pilar 2); and "social justice for all of the people of Indonesia" (Pilar 5). Soekarno, and the founding fathers of the Indonesian Republic, considered the concept of unity as an expression of nationalism, standing in opposition to colonialism at the beginning of Indonesia's independence. However, in the post-colonial period, 'imperialism' no longer refers to dominance solely by foreign powers, but also internal domination. The power struggles that led to the atrocities of the 1965 genocide forced exiles at the beginning of the reformation of 1997-1998, and the systematic human rights abuses during the New Order regime, are some of the most well-known examples of internal colonial practices in Indonesia. Therefore, it is not sufficient for the concept of 'unity' to be seen solely as nationalism against a colonial power.

Since unity can be destroyed by internal colonial mentality, a true nantionalism based on solidarity (Pilar 3) and nurtured by humanism (Pilar 2) and social justice (Pilar 5), as adovocated in Pancasila, needs to be materialized in the community life of the Indonesian people. This solidarity should not only include present victims of human rights abuses, but also victims of past State-sponsored terror and violence. Without a serious policy for redressing the rights of victims, the perpetrators of crimes against humanity will continue with impunity and similar violations are likely to occur again in the future. This is damaging to national unity. To maintain a stable national unity, solidarity in the form of reconciliation with the victims is of particularly important. Without proper mechanisms to establish responsibility and accountability victims of state crime, morality, as enshrined in Pancasila, would be a meaningless foundation to the social contract.

\section{Pancasila and State-Religion Relationship}

Discussion regarding the differentiation of and relation between State and religion is an intellectual attempt to establish the position and role of religion in a liberal community or State. Rawls' political theory of justice has helped bring this discussion to prominence. For Rawls, religious freedom is one of the most basic forms of liberty and 
having a 'true religion' is not irreconcilable with responsibility within a liberal State. ${ }^{29}$ This political theory of justice implies that secularity, as separation between the State and religion, in liberal communities does not mean bannishing religious liberty completely from the public sphere of the State.

Since one of the main purposes of State is to maintain peace and order, State's must ensure religious liberty without demonstratble favorability towards any particular religion. Failure to do so may pose threat to peace and order of the society. State's may insure against the adverse effects of religious conflict by requiring the coexistence of citizens from varying religious backgrounds and comply with rule of law that governs the society when exercising their religious liberty.

In Germany, the dialectic relationship between State and religion drew the attention of the former president of the German Constitutional Court, Ernst Wolfgang Böckenförde. Witnessing the suspension of civil liberties, the trend toward the rejection of pluralistic and secularized democracy under the Nazi regime, and the rapprochement between Catholicism and the Nazi's, he captured the paradox embodied by modern democratic States. He wrote, "Der freiheitliche, säkularisierte Staat lebt von Voraussetzungen, die er selbst nicht garantieren kann" ("the liberal, secularized state lives on the basis of assumptions that it itself cannot guarantee). ${ }^{{ }^{30}}$ This paradox, according to Böckenförde, must be accepted by each liberal-secular State which values plurality and wants to safeguard individual freedom.

A modern democratic State can only exist legitimately if it is capable of guaranteeing and protecting the freedom of each citizen. On the one hand, individual freedom (civil liberty) is the purpose and reason for the existence of the State. On the other hand, at the core of that freedom is one's conscience which cannot be dictated according to the norms of positive law. When positive law is used to intervene the private realm of an individual's conscience, the State has become totalitarian. ${ }^{31}$ Böckenförde's political thought has dramatically influenced the political theory and practice in modern Europe. It has led them out of the bloody religious and ethnic wars which swamped Europe in the $17^{\text {th }}$ century. The fact that Europe has been able to maintain its general peace up to present day can be said, in part, because of the concept of a liberal-secular State.

In such a condition, human freedom is expressed as autonomus decision-making and respect for individuals conscience which can never be coerced by external powers. ${ }^{32}$ Freedom can only be regulated internally, according to the morality of each individual

29 Rawls, supra note 8 at 181.

30 Ernst-Wolfgang Böckenförde, Staat, Gesellschaft, Freiheit: Studien zur Staatstheorie und zum Verfassungsrecht (Frankfurt am Main: Suhrkamp Verlag AG, 1976) at 60.

31 Ibid.

32 Franz Magnis-Suseno;, Etika Politik: prinsip-prinsip moral dasar kenegaraan modern (Jakarta: Gramedia Pustaka Utama, 1999) at 348. 
and the homogeneity of a society. The danger of totalitarianism emerges when a State begins making laws intended to control the conscience and personal integrity of its citizens. In this scenario, the State seeks total control of all aspects of life, including the way of thinking and morality of its citizens. This ambition is not only impossible to realise but is also incompatible with the very nature of a liberal democratic State. Such a project poses a direct attack on peace, denying the plurality of culture, religion, behavior, and freedom of thought.

Pancasila, as an ideology of multicultural Indonesian society, must avoid the less constructive communitarian tendency to take issue with the distinction between the State and the religion, between the person and ethics, while trying to establish a "true" nation based on religion or a particular system of belief. This intolerant communitarian tendency is illustrated by religious fundamentalism in Indonesia. The fundamentalists terrorise and legitimize violence to destroy other groups. By plowing procedural democracy, fundamentalist groups have succeeded in creating numerous culturally intollerant laws and hundreds of local regulations with Syariah connotations. ${ }^{33}$ The ideal of building a nation based on a particular ideology or religion is a retrograde step in history. In order to respond constructively to this, a procedural democracy must be complemented by a substantive democracy that can control and limit the exercise of power and the will of the majority or other dominant groups. Substantive democracy is a basic human right, the values of which are also found in Pancasila.

Pancasila does not promote the idea of a single national religion for Indonesia. Nor does it endorse the liberal view that religion is a purely private matter. Instead, Pancasila promotes religious values as the basis of public morality. In this regard, the concept of God enshrined in Pancasila becomes a public morality that guides civic religion, and is not primarily a private morality for individual beliefs. As Yudi Latif correctly notes:

"...in the framework of belief in God, an individual might not personally follow a formal religion, such as an agnostic or even an atheist. However, in public life that person must respect the values of divinity as expressed in Pancasila, based on the results of a constitutional agreement. There is no place for anti religious propaganda. ${ }^{{ }^{34}}$

By underlining the importance of the public role of religion, Pancasila corrects the liberals' thesis of the privatization of religion, while recommending a paradigm for differentiating the relationship between religion and the state. This is because, when religion is completely removed from the public arena, and is confined to the private domain, an expression of personal spirituality that disconnects with public domain

33 Adnan Buyung Nasution, Demokrasi konstitusional: pikiran \& gagasan (Jakarta: Penerbit Buku Kompas, 2011) at 122.

34 Yudi Latif, Negara paripurna: historisitas, rasionalitas, dan aktualitas Pancasila (Jakarta: Kompas Gramedia, 2011) at 112. 
emerges. On the other hand, secular politics can disregard religious values and ignore the moral significance of belief in God. This can lead to the creation of a situation whereby both sides simply ignore one another. Spirituality without social responsibility and politics without a soul (spirituality) may emerge. ${ }^{35}$ This is one of the main reasons why both religious and secular fundamentalism should be avoided. The fact that corruption is so rampant in a self-proclaimed religious country like Indonesia indicates that religion is still seen as a rigid, private concern, and has not become a moral strength in the public arena.

The public role of religion is to defend its freedom and the freedom of other religions. Religion can challenge the tendency toward absolutism in the secular world, including the absolute power of the State. ${ }^{36}$ In the midst of the current globalized world marked by boundless technological expansion and domination of anonymous power over various aspects of life (Lebenswelt), religion can become a spring of life, providing ethical guidelines for society. Belief in $12 \mathrm{ft}$ he enshrined in Pancasila, expresses the commitment of Indonesian people to structure their public and political life around universal moral principles, with nobility of mind and character. The moral crisis faced by modern society, together with the phenomen of religious growth in secular society, ${ }^{37}$ makes the divine aspect of the Pancasila increasingly relevant in dealing with changes arising from internal and global transformations.

The secular paradigm that has characterisedWestern society since the 90 s, placing religion in the private domain on the periphery of society has begun to erode. Religious matters once again began to be discussed in the public arena. ${ }^{38}$ Habermas, a selfproclaimed non-religious talent ("religiős unmusikalisch"), for instance, began to rethink the important role of religion in public life. While characterizing the modern liberal world as 'postsecular,' Habermass calls society to anticipate the continuous existence of religious communities and their contribution to constructive attittudes including solidarity and normative awareness-building. ${ }^{39}$ For that purpose, procedurally, the State must be neutral about the conception of good, while both secular and religious communities need to fundamentally change their mentality with regard to normative values in a liberal State. Substantively, the society as a whole (both secular and religious ones) need to be aware of the unique power a religous tradition has for voicing moral wisdom and truth that can be learned by all segments of society. ${ }^{40}$

35 Ibid at 104.

36 Ibid at 109.

37 Jonathan Benthall, Returning to Religion: Why a Secular Age is Haunted by Faith (London: I.B. Tauris, 2008); William P Marshall, "The Limits of Secularism: Public Religious Expression in Moments of National Crisis and Tragedy" (2002) 78:1 Notre Dame Law Review 11.

38 Otto Gusti Madung, "Etos Global dan Dialog Peradaban”, Kompas (27 February 2010) at 6.

39 Jürgen Habermas, Between Naturalism and Religion: Philosophical Essays, 1st edition ed, translated by C. Cronin (Cambridge: Polity Press, 2008) at 111 Translators: _:n3910.

40 Ibid at 131. 
While Habermas looked at the public role of religion from his position as a nonreligious scholar, Hans Küng- highligthed the public role of religion in society based on his scholarly background as a Catholic theologian. In addressing modern secular society, which tends to limit religion to private arena, Kűng insisted, "Even though humans insist on being obedient to moral norms, there is one thing that cannot be done without religion, that is, to give a foundation for the certainty and universality of moral imperatives." ${ }^{\prime \prime}$ The need for universal moral norms, according to Kűng, cannot be found solely in abstract philosophical argumentation. Philosophy is only able to touch human intellect, whereas the essential need for moral norms can rouse human feelings in the realm where religions can break forth and move. As such, the crisis of morality in modern society demands an active role of religion in the public arena.

Habermas' and Küng's views regarding the public role of religion provide valuable lessons for measuring a balanced and constructive application of religion in the public arena, as recognised in Pancasila, to strenghten social cohesion in Indonesia. Recently such a balanced and constructive public role of religion was voiced by the newly appointed Religious Affairs Minister, Yaqut Cholil Qoumas, in his statement, "to make religion an inspiration rather than aspiration." ${ }^{22}$ This implies a recognition of religion as a source of moral imperatives that can help religous communities provide constructive contributions to peace and order in a pluralistic society. While it may sound promising, the extent to which such a promise can be materialized will very much depend on how well the democratic system allows the public aspect of religion, as a moral imperative, to function in the pluralistic society of Indonesia.

\section{Pancasila, Pluralism, and Democracy}

Understanding to what extent pluralism and democracy provide a necessary condition for strenghtening Pancasila as a collective identity and moral ground for a pluralistic society, it is necessary to consider a small segment of history that significantly influenced the idea of Pancasila. Between 1934 and 1938, Soekarno, the first Indonesia President, lived in exile in Ende, Flores where he befriended Catholic missionaries from Holland, and members of the Society of the Divine Word (known in Latin as Societas Verbi Divini or SVD). ${ }^{43}$ Two particularly notable friends were the late Fr. Johanes Bouma and Fr. Gerardus Huijtink. While there, Soekarno used to visit the library of the SVD missionaries in the Saint Joseph Convent and enjoyed discussing various issues with the missionaries. These discussions raised serious questions about the role of Pancasila as an ideological foundation of the pluralistic society of Indonesia:

41 Hans Kűng, "Leitlinien zum Weiterdenken" in Hans-Martin Schönherr-Mann, ed, Miteinander leben lernen: Die Philosophie und der Kampf der Kulturen (Műncehen: Piper Verlag, 2008) at 387.

42 Yaqut Cholil Qoumas, Accepting Speeach as the New Ministry of Religous Affairs of the Republic of Indonesia, Jakarta, 23 December 2020.

43 Tim Nusa Indah, Bung Karno dan Pancasila (Ende: Penerbit Nusa Indah, 2006). 
1) "How does your mother, a Hindu, fit into a country which has a Muslim majority?"

2) "How do the people of Flores, the majority of whom are Catholic, fit into a Marxist state with a Muslim majority. ${ }^{\prime \prime \prime}$ These questions implied that the diverse socio-religious background of Soekarno's family and nation prompted his realization that Pancasila could become a basis for collective identity. Through this, all persons and groups with different belief systems can authentically coexist without endangering others.

Pancasila has since been considered a central political ideology used to strengthen social cohesion in Indonesia's pluralistic society. The challenges faced by modern Indonesia are radically different from those that characterised the early days of independence. As a member of the international community, Indonesia takes part in the realization of global values such as democracy, basic human rights, and the freemarket economy. Openness to the global community makes the pluralistic reality of society increasingly complex. It raises fundamental questions including: What does it mean for Pancasila to guarantee of social cohesion in a complex pluralistic society like Indonesia? How can Pancasila guarantee social cohesion, by holding up the principle of pluralism, while at the same time remaining relevant to the ongoing process of democratisation in most aspects of its society?

To answer these questions, it is useful to consider three interpretations of the concept of 'pluralism' which commonly appear in philosophical debates about social cohesion. Firstly, pluralism is interpreted neutrally when used to describe the condition of a society that is diverse and multi-faceted. ${ }^{45}$ In a democratic society, freedom of thought is held very highly. Every citizen is free to choose his/her view of life, career and political persuasion. In such a context, pluralism describes a social diversity which is at the core of a democratic society.

Secondly, pluralism can be interpreted as a positive force. ${ }^{46}$ Here, pluralism is not meant to describe a heterogenous society, but is a normative concept interpreted as the basic common value of life. Each person is free to think, act, and believe in such a way as to bring together diverse individuals, groups, and communities, overcoming division and conflict while guaranting fair treatment through inclusion and participation. In order to achieve this, a pluralistic society needs both 'hardware factors' - intitutions and norms - that protect and nurture diversity, and the 'software factor' - cultural habits -

44 John Dami Mukese, "Bung Karno, SVD dan Pancasila" in Otto Gusti Madung \& Antonio Camnahas, eds, Ut Verbum Dei Currat: 100 Tahun SVD di Indonesia (Maumere: Penerbit Ledalero, 2013) at 299.

45 Patrick Dunleavy \& Brendan O’Leary, "Pluralism” in Patrick Dunleavy \& Brendan O’Leary, eds, Theories of the State: The politics of liberal democracy (London: Palgrave Macmillan, 1987) 13 at $13-71$.

46 Isaiah Berlin, "On the Pursuit of the Ideal” The New York Review of Books (17 March 1988) at 1118. 
based on true conceptions about national identity and historical naratives. ${ }^{47}$ These 'factors' create a liberal society where people can live together in peace. Pluralism, here, determines social bonds and serves as a guarantee for social cohesion.

Thirdly, pluralism can have negative connotations. It can be seen as a threat to social harmony because diversity is perceived as something that can destroy social cohesion. This may happen when pluralism is understood within the prism of multiculturalism that emphasizes the non-assimilation of ethic and racial differences. ${ }^{48}$ Pluralism is understood as a sign of weakness concering social norms, or an indication of the absensce of collective norms. In this sense, pluralism is perceived as a symptom of the disappearance of social solidarity in a complex society. Pluralism is blamed as the cause of egoism, cultural alienation, and crises of solidarity. Futhermore, any act for partial interest, such as lobbying and personal orientation in political decision-making processes that may lead to the destruction of democratic principles are considered to be rooted in pluralism. ${ }^{49}$

Despite these different perceptions, pluralism requires a social unity based on either a cultural identity or a collective political value. What is needed in a liberal society goes beyond official uniformity. It is not sufficient for citizens to simply have the same rights. Society must have a collective view to establish a solid foundation for social norms. This collective view is particularly needed in modern society which struggles to navigate the tension between the process of individualisation and the demands of the community. On the one hand, there is a desire for greater autonomy and personal determination in decision making processes about private matters, even if these decisions challenge commonly accepted norms of the community. On the other hand, a person or individual is always part of a larger group or community. Acting against communal intersts will weaken communal unity and endanger peaceful coexistence among diverse individuals and groups of people in a society.

In social philosophy, Isaiah Berlin, among others, has made an intensive study regarding the relationship between pluralism and the process of forming a community. In his view, modern society is built upon the basic values of freedom and universal equality. However, these basic values are often in conflict in a pluralist society. According to Berlin, efforts to harmonise these basic values tends to allow a form of totalitarianism. ${ }^{50}$ Therefore, modern society certainly needs a public discourse to guide the application of these values to the concrete socio-political contexts. A reasonable and democratic public discourse regarding the application of those collective values in

47 Jane Jenson, "Intersections of Pluralism and Social Cohesion: Two Concepts for the Practice of Pluralism” (2019) Global Centre for Pluralism 25 at 3.

48 Jane Barnes Mack, "Culural Pluralism and Multiculuralism: E Pluribus Umum or Ex Uno Plura?" (1994) 26:2 Hitotsubashi Journal of Social Studies 63-72.

49 Bellamy, supra note 7 at ix.

50 Ibid at 16. 
the concrete condition of a community can create social cohesion. Otherwise it can be too excessive and exclusive and may result in an intolerant political identity.

The creation of Indonesia's collective identity was marked by the conflicting values. This is demonstrated by the debate between Soekarno and Mohammad Natsir about the relationship between the State and religion (Islam). ${ }^{51}$ Representing the secular nationalists, Soekarno argued for the separation of state and religion. Mohammad Natsir voiced the aspirations of the Islamic nationalists who were in favour of a connected state and religion (Islam). Their basic argument was that religion is not only about the relationship between humanity and God, but also the way people relate to each other in a political structure.

Similar sentiments continue to be expressed by different Islamic groups today. ${ }^{52}$ Liberal Islamic groups are faithful to Soekarno's separation of State and religion. They advocate for secularisation in Islam, popularized by Nurcholish Madjid, and followed by scholars of the liberal Muslim camp such as Ulil Abshar Abdalla, Luthfi Assyaukanie and Akhmad Sahal. Their work focuses on how Islam can constructively cope with the challenges of modernity such as pluralism, individual rights, democracy, and the concept of the State..$^{53}$ Alternatively, literal Muslim groups advocate for Natzir's non-separation idea. These ideas are represented in the works of Adian Husaini, Hartono Ahmad Jaiz, Ja'far Umar Thalib, and Habib Rizieq, among others who promote the formation of an Islamic State. This is largely based on the historical fact that Madinah once was an Islamic State, which had the world's first national constitution, known as the Madinah Charter. The Prophet Mohammed himself was the head of State. The country was governed according to Syariah rules and cultural laws. ${ }^{54}$

Resolving these ongoing tensions requires an open and reasonable public discussion without prejudice or claims to the 'only' religous truth. As a guide for this public discourse Pancasila should not be seen as a dead formulation. It should be thematised and re-interpreted rationally to become a living collective identity.

Two political philosophy models for the establishment of a collective identity in a pluralistic democratic society - Jürgen Habermas' deliberative democracy and Chantal Mouffe's radical democracy - may help resolve Indonesia's struggle with the conflict between values. Habermas' philosophical works all carry a similar sentiment of enlightenment. He aims to promote emancipation, democracy, and social participation in political processes, while simultaneously contributing to the public discourse. His philosophy emerges from day-to-day conversation. Through various forms of conversation, communication is built. This is the basic foundation of the theory of

51 Ahmad Suhelmi, Polemik negara Islam: Soekarno versus Natsir (UI Press, Jakarta, 2012).

52 Wilden Sena Utama, "Negara (dan) Islam. Sekitar Polemik Soekarno dan Natsir" Prisma Majalah Pemikiran Sosial Ekonomi (2013) at 262.

53 Ibid.

54 Ibid at 263. 
discourse. In this regard, language is not only an intersubjective form, but is also a fundamental step towards emancipation and communication, because when a first sentence is stated, an unforced universal consensus is actualised. ${ }^{55}$

The basis of this theory of democracy is a concept of society based on three components: the living world (Lebenswelt), public arena (Öffentlichkeit), and political system. ${ }^{56}$ Lebenswelt is expressed in various models of human communication. Humanity intuitively acts communicatively and seeks communication in daily life. At the same time, the principle of public expression plays role in responding to all the problems that arise in Lebenswelt. It gives voice to problems in the public arena while trying to influence the political system.

The ethical principle of discourse is that norms are only considered valid if they are accepted as such or agreed by general consensus. ${ }^{57}$ This principle is based on the assumption that a person who implicitly engages in argumentation is aware of the guiding principles of the discussion. A speaker must always accept those rules. Otherwise, they will fall into a performative contradiction. As such, the discourse ethic begins from the reality of Lebenswelt. A discourse ethic is a formal ethic. Influenced by the tradition of Kantian enlightenment, Habermas is of the opinion that people can communicate rationally and build a consensus in discourse. This communicative rationality provides a basis for dialogical ethics. ${ }^{58}$ Norms for common living can only be found in processes of dialogical argumentation, and not from monological speculation.

In many of his writings, Habermas demonstrates the successful political expression of a philosophical viewpoint. A key example of this is the concept deliberative democracy. ${ }^{59}$ This is a process of de-institutionalizing the proces of forming public opinion. In this way, the maximum possible number of citizens participate in discourses about critical questions about public life. Public awareness emerges spontaneously, it is creative and decentralized by nature, guaranteeing the plurality of public opinion. The purpose of this process is communicative formation of a rational consensus. This is the only way norms in community life can be sufficiently legitimised, and can encourage citizens to realise them in their individual Lebenswelt.

Applying Habermas' view of social cohesion in the Indonesian context, Pancasila as a collective identity can only succeed and become a legitimate goal if it considers an ethical view of discourse. If a society creates a proceedure within which everyone can participate, and the purpose of the proceedure is the construction of a rational

55 Jürgen Habermas, Technik Und Wissenschaft Als Ideologie (Frankfurt am Main: Suhrkamp, 1968) at 163.

56 Pfeifer, Cojocaru \& Reder, supra note 21 at 14.

57 Jürgen Habermas, Moralbewusstsein und kommunikatives Handeln (Frankfurt am Main: Suhrkamp, 1983) at 103.

58 Pfeifer, Cojocaru \& Reder, supra note 21 at 14.

59 Jürgen Habermas, Faktizität und Geltung. (Frankfurt am Main: Suhrkamp, 1992). 
consensus to deal with conflicting values, then the deliberative design of this is a guarantee of social cohesion or social unity. Pancasila, as the fruit of a deliberative proceedure portraying communicative rationality, can strengthen the unity of the pluralistic Indonesian society.

The term post-democracy has become a population antithesis of the concept deliberative democracy in philosophical discourses. According to Chantal Mouffe, democracy is marked by a paradox which is not accommodated in the deliberative democracy theory. ${ }^{60}$ This paradox appears because democracy attempts to bridge two contradictory concepts, namely, individual freedom and the principle of egalitarianism. According to Mouffe, the tension between these fundamental concepts cannot be ignored and must be an inspiration for the democratic movement.

In 1985 Mouffe, together with Laclau, laid out the socio-philosophical foundation for his views on democracy. ${ }^{61}$ According to him, the social does not just unfold in a positive way before us. Rather, it actualises itself as a fruit of complex discourse. For Mouffe, it's not a reference to the empirical world what gives meaning, but rather meaning is only constructed in the midst of social and political discourse. Discourse is a fruit of social totality which constantly changes. Based on that dynamism, and the impossibility of reducing the social to a single meaning, 'society' is always questioned and fragile. As a result, new things constantly appear and prompt discourse. This

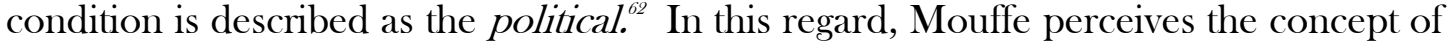
democracy as a pluralisation of political conflicts. Given that, and in line with the discussion above, the process for solving this conflict may give rise to totalitarianism, Mouffe puts forward a conceptual transformation from antagonism to agonism of the socio-political powers. The existence of enemies is not necessary, but rather opposition which can see the win-lose positions in political discourse as a chance for a democracy to flourish.

From a radical democratic perspective, Mouffe criticises Habermas' concept of deliberative democracy. In his opinion, Habermas, and other liberal thinkers, do not really see politics as an open arena of conflict. Certainly, Mouffe does not perceive such conflict as a debate between individuals, but rather as a conflict in community. ${ }^{63}$ Therefore, he pays special attention to discursive power relations. Mouffe's second criticism argues that liberal democratic theory ignores relationships in a society. Mouffe interprets the militant moment (Leidenschaft) as a motor which powers the democratic process. He insists, "Politics always has a dimension of militancy and alignment... And

60 Chantal Mouffe, Das demokratische Paradox, translated by Oliver Marchart (Wien: Turia Verlag, 2008) Translators:_:n3982.

61 Ernesto Laclau \& Chantal Mouffe, Hegemony and Socialist Strategy: Towards a Radical Democratic Politics, 2nd edition ed (London: Verso, 1985).

62 Ibid at 125-127.

63 Chantal Mouffe, "Deliberative Democracy or Agonistic Pluralism?” (1999) 66:3 Social Research $745-758$. 
this is what has disappeared in the present time, when democracy has been glorified without a sense of militancy and alignment. ${ }^{{ }^{64}}$

Additionally, the concept of radical democracy can be reduced to a critique for understanding liberal rationality. Liberal thinkers expound a formal understanding of common sense which is also very monolithic. Post-modernism thinker Wolfgang Welsch criticizes the monological rationality of Habermas due to his desire to return plurality to unity, despite his failure to provide an unterpretation of unity. ${ }^{65}$ So, the plurality of public opinion is relegated to private irrationality.

From a viewpoint of anti-essentialistic theory, pluralism is not just a fact which must be accepted, grinning and bearing it, but rather it is an axiologic principle. Conceptually, from the essence of modern democracy, the axiological principle is regarded as being constitutive, and is seen as something to be accepted and developed. ${ }^{66}$

Compared with the theory of deliberative democracy, radical democracy emphasises that the primary place of social cohesion cannot be created by communicative rationality or a deliberative procedure alone, but also requires a discursive political struggle. This discursive struggle refers to an understanding and framing of an issue in a puclic discourse and its ability to motivate action. ${ }^{67}$

Pancasila becomes a collective identity when it becomes the object of a discursive struggle. In this way, Pancasila will be protected from the risk of an interpretative monopoly as occured during the New Order regime. In the absence of public participation and communication in a discursive struggle, the New Order regime very often promulgated false interpretations of Pancasila. When political discourse about Pancasila as the nation's collective identity is promoted, Indonesian citizens will own the nation's politics. Emphasising the significance of consensus through political discourse, the theory of deliberative democracy gives more attention to the function of community formation rather than to pluralism and discursive struggle. In fact, in the pluralistic context of Indonesia, discursive struggle must be continually promoted for Indonesia to become a truly political entity. Pancasila must be continually constructed in political discourse for its very existence as an ideological foundation and national collective identity to be realised.

64 Mouffe, supra note 6 at 40.

65 Wolfgang Welsch, Vernunft. Die zeitgeössische Vernunftkritik und das Konzept der transversalen Vernunft, first edition ed (Frankfurt am Main: Suhrkamp, 1995) at 139.

66 Mouffe, supra note 60 at 35.

67 Deborah Stone, Policy Paradox: The Art of Political Decision Making, 2nd ed ed (New York: W. W. Norton \& Company, 2002). 


\section{CONCLUSION}

Pancasila is formulated as an ideological basis in the sense that it expreses a collective identity which aims to unite pluralistic Indonesia into a political unity. Despite its strength as a drive for national unity, in practice the process of the dogmatization of Pancasila and partial political discourse among different segments of society has obscured its meaning and weakened its political relevance as a collective identity. This article has shown that, firstly, in order to revive its strength as a collective identity, as originally perceived by the founding fathers, Pancasila needs to be reinterpreted and given a place in the contemporary political discourse, where its fundamental values and their relevance remain open for inclusive and democratic public discusions. The urgency for reinterpretation through public discourse gains momentum through the democratisation process and the openness to globalisation (external factors) and the ongoing partial ideological pursuit for political power and dominance through a nonseparation State-religion form of government by certain religous fundamentalist groups (internal factor). These external and internal factors have given rise to conflicts of values in Indonesia's pluralistic society as new values and partial idiological views began to challenge and pose risks to commonly accepted idiological values of Pancasila. Throughout Indonesia's history, particularly since the end of the New Order regime, the nation's inability to establish the ideological values of Pancasila as a collective identity in managing conflicting values has led to various forms of violence, including massive human rights abuses, that threathen the peaceful order of society and weaken its social cohesion. In this regard, the reinterpretation of Pancasila should help to revive and stregthen the ideological values of Pancasila as moral imperative for coexistence between citizens under a stable collective identity. In practice, this must be demonstrated in the implementation of Pancasila as a gurantee of the enjoyment of fundamental human rights by all Indonesian citizens.

Secondly, despite the process of democratisation that has been taking place in Indonesia since the begining of the reformation period, its effectiveness to create an inclusive public discourse to strengthen Pancasila as a national collective identity is dependent on approches to manage conflicting values in its pluralistic society. Liberal political philosophy, particularly Ralws's principle of liberty (equal treatment) and principle of difference (equal distribution) on the basis of "original posisition" (without pre-assumption of priviledge and advantage) may provide a constructive conceptual approach to mediate conflicting values and to reach fair agreements and consensus among the diverse citizens of Indonesia. Building a conceptual structure of justice on the basis of the principles of liberty and difference is denial of freedon under the authoritarian New Order Regime, but also the exesive use of freedom at the expense of other people's freedom and inequal distribution of resources and opportunities by certain segments of the society since the beginning of the reformation.

Notwithstanding, given the difficulty of maintaining consistent moral values in a pluralistic society with fair, liberal democratic procedures, a communitarian perpective 
for understanding the values of Pancasila as normative foundation of justice and common identity needs to be rooted in community. This is because conflicting values in a pluralistic society reflects the concrete conditions of diverse individuals and groups. Unless reasonable and rational public discourse for understanding and reinterpreting Pancasila provides common ground for a fair consensus and agreement in dealing with conflicting values among those individuals and groups in Indonesia, plurality will remain the key obstacle to its social cohesion. In order to address this obstacle, deliberative democracy, which allows every citizen to participate in a rational public discourse for a fair and resonable consensus, may become an effective approach. This deliberative democracy requires a discursive process in which Pancasila is taken as an object for rational and reasonable public discourse. However, a meanigful and effetive public discourse, must be backed up by improved education and awareness of: (1) the values of Pancasila and their role as moral imperatives for interactions and as a source of social cohesion in a pluralistic society; and (2) the significance of engaging in deliberative and discursive processes to materialize Pancasila as the ideological foundation of national collective identity.

\section{BIBLIOGRAPHY}

Bellamy, Richard, Liberalism and Pluralism: Towards a Politics of Compromise (London: Routledge, 1999).

Benthall, Jonathan, Returning to Religion: Why a Secular Age is Haunted by Faith (London: I.B. Tauris, 2008).

Böckenförde, Ernst-Wolfgang, Staat, Gesellschaft, Freiheit: Studien zur Staatstheorie und zum Verfassungsrecht (Frankfurt am Main: Suhrkamp Verlag AG, 1976).

Brighouse, Harry, Justice (Cambridge: Polity, 2004).

Habermas, Jürgen, Between Naturalism and Religion: Philosophical Essays, 1st edition ed, translated by C. Cronin (Cambridge: Polity Press, 2008).

—, Faktizität und Geltung. (Frankfurt am Main: Suhrkamp, 1992).

—- Moralbewusstsein und kommunikatives Handeln (Frankfurt am Main: Suhrkamp, 1983).

—_, Technik Und Wissenschaft Als Ideologie (Frankfurt am Main: Suhrkamp, 1968).

Hatta, Mohammad, Kumpulan karangan (Jakarta: Penerbit Bulan Bintang, 1976).

Laclau, Ernesto \& Chantal Mouffe, Hegemony and Socialist Strategy: Towards a Radical Democratic Politics, 2nd edition ed (London: Verso, 1985).

Latif, Yudi, Negara paripurna: historisitas, rasionalitas, dan aktualitas Pancasila (Jakarta: Kompas Gramedia, 2011). 
Magnis-Suseno;, Franz, Etika Politik : prinsip-prinsip moral dasar kenegaraan modern (Jakarta: Gramedia Pustaka Utama, 1999).

Magnis-Suseno, Franz, Pijar-pijar Filsafat: Dari Gatholoco ke Filsafat Perempuan, dari Adam Muller ke Postmodernisme (Yogyakarta: Kanisius, 2005).

Mouffe, Chantal, Das demokratische Paradox, translated by Oliver Marchart (Wien: Turia Verlag, 2008).

—, Über das Politische: Wider die kosmopolitische Illusion (Frankfurt am Main: Suhrkamp Verlag AG, 2007).

Nasution, Adnan Buyung, Demokrasi konstitusional: pikiran \& gagasan (Jakarta: Penerbit Buku Kompas, 2011).

Rawls, John, A Theory of Justice Revised Edition, revised edition ed (Massachusetts: Harvard University Press, 1999).

—_, Political Liberalism (New York: Columbia University Press, 1993).

Sandel, Michael J, Liberalism and the Limits of Justice (Cambridge: Cambridge University Press, 1982).

Stone, Deborah, Policy Paradox: The Art of Political Decision Making, 2nd ed ed (New York: W. W. Norton \& Company, 2002).

Suhelmi, Ahmad, Polemik negara Islam: Soekarno versus Natsir (UI Press, Jakarta, 2012).

The Consitution of the Republic of Indonesia, 1945.

Tim Nusa Indah, Bung Karno dan Pancasila (Ende: Penerbit Nusa Indah, 2006).

Walzer, Michael, Sphären der Gerechtigkeit: Ein Plädoyer für Pluralität und Gleichheit (Frankfurt am Main: Campus Verlag GmbH, 1992).

Welsch, Wolfgang, Vernunft. Die zeitgeössische Vernunftkritik und das Konzept der transversalen Vernunft, first edition ed (Frankfurt am Main: Suhrkamp, 1995).

Yamin, Muhammad, Naskah-persiapan Undang-undang Dasar 1945: disiarkan dengan dububuhi tjatatan (Jakarta: Jajasan Prapantja, 1959).

Berlin, Isaiah, "On the Pursuit of the Ideal" The New York Review of Books (17 March 1988).

Dami Mukese, John, "Bung Karno, SVD dan Pancasila" in Otto Gusti Madung \& Antonio Camnahas, eds, Ut Verbum Dei Currat: 100 Tahun SVD di Indonesia (Maumere: Penerbit Ledalero, 2013).

Dunleavy, Patrick \& Brendan O'Leary, "Pluralism” in Patrick Dunleavy \& Brendan O'Leary, eds, Theories of the State: The politics of liberal democracy (London: Palgrave Macmillan, 1987) 13. 
Gumbira, Seno Wibowo \& Jamal Wiwoho, "The Implication of the Globalization on the Pancasila-Based Principles of Local Democracy in Indonesia” (2019) 6:2 Padjadjaran Journal of Law 361-378.

Huddy, Leonie, David O Sears \& Jack S Levy, eds, "Values, Ideology, and the Structure of Political Attitudes" in The Oxford Handbook of Political Psychology: Second Edition (Oxford: Oxford University Press, 2003).

Jenson, Jane, "Intersections of Pluralism and Social Cohesion: Two Concepts for the Practice of Pluralism” (2019) Global Centre for Pluralism 25.

Jovanovic, Miodrag, "Recognizing Minority Identities Through Collective Rights" (2005) 27:2 Human Rights Quarterly 625-651.

Kűng, Hans, "Leitlinien zum Weiterdenken” in Hans-Martin Schönherr-Mann, ed, Miteinander leben lernen: Die Philosophie und der Kampf der Kulturen (Műncehen: Piper Verlag, 2008).

Lynch, Kathleen \& Manolis Kalaitzake, "Affective and calculative solidarity: The impact of individualism and neoliberal capitalism" (2018) 23:2 European Journal of Social Theory 238-257.

Mack, Jane Barnes, "Culural Pluralism and Multiculuralism: E Pluribus Umum or Ex Uno Plura?” (1994) 26:2 Hitotsubashi Journal of Social Studies 63-72.

Madung, Otto Gusti, "Etos Global dan Dialog Peradaban”, Kompas (27 February 2010).

Marshall, William P, "The Limits of Secularism: Public Religious Expression in Moments of National Crisis and Tragedy" (2002) 78:1 Notre Dame Law Review 11 .

Mouffe, Chantal, "Deliberative Democracy or Agonistic Pluralism?” (1999) 66:3 Social Research 745-758.

Pfeifer, Hanna, Mara-Daria Cojocaru \& Michael Reder, "Was hält Gesellschaft zusammen? Eine Einführung" in Was hält Gesellschaften zusammen? Der gefährdete Umgang mit Pluralität (Stuttgart: Kohlhammer, 2013).

Utama, Wilden Sena, "Negara (dan) Islam. Sekitar Polemik Soekarno dan Natsir" Prisma Majalah Pemikiran Sosial Ekonomi (2013).

Walzer, Michael, “The Communitarian Critique of Liberalism” (1990) 18:1 Political Theory.

Otto Gusti Madung is a lecturer at the Ledalero Catholic School of Philosophy, Maumere, Flores, Nusa Tenggara Timur, Indonesia. He obtained his bachelors degree and his master's degree of theology from Institute of Philosophy and Theology, St. 
Gabriel, Mődling bei Wien, Austria. He completed his PhD at the Institute of Philosophy, Munich, Germany. The title of his thesis is "Politik und Gewalt: Giorgio Agamben und Juergen Habermas im Vergleich" (Politics and Violence: A Comparative Study of Giorgio Agamben and Juergen Habermas). His teaching includes political philosophy, human rights, and history of contemporary philosophy. He has published several scholarly articles and books in the areas of human rights, political philosophy, and democracy.

Winibaldus Stefanus Mere holds an LLM in International Law with International Relations from the University of Kent, Canterbury, and a PhD in Law (Human Rights Law) from SOAS, University of London, UK. He is currently an Associate Professor in the Faculty of Law and Senior Research Fellow at the Institute for Social Ethics, Nanzan University in Nagoya, Japan. While his recent research project focuses on the legal, social, and spiritual responsibility of business enterprises regarding human rights and the environment, he writes about a wide range of political and human rights-related issues. 